\title{
Penerapan Aplikasi iDINI sebagai Media Penyimpanan Materi Perkuliahan iLearning Pada Perguruan Tinggi
}

\author{
Untung Rahardja \\ Ary Budi Warsito \\ Dini Nurul Suvianti \\ Email: untung.raharja@faculty.raharja.ac.id, ariebhewe@gmail.com \\ dininurulsuvianti@si.raharja.c.id
}

\begin{abstract}
Era of globalization is happening now require human resources to complete, on the other side of Indonesia's human resources do not meet the above criteria. Even qualitatively, the fact shows that Indonesia's human resources is quite low and tends to decrease. Low indicators of human resources of Indonesia can be seen in student achievement. The problem is still quite low level of education of Indonesia's human resources is a challenge for the state of education in Indonesia. Indonesia needs to improve the quality of education for human resource produced as expected, decreased detection performance learn should start from the educator as the spearhead of educational success .. This method can optimize the potential of intellectual, social and emotional development of students. This is one thing why the medium of learning is necessary in the learning process. Medium of learning is one component of learning that has an important role in the learning process. Use of media should be a part that should receive the attention of teachers as facilitators of learning in every activity. Because of its individual that educators need to learn how to establish a medium of learning in order to effectively achieve the goal of learning in the learning process. In fact the learning media is still often overlooked by many reasons.
\end{abstract}

Keyword : education, iLearning, the effectiveness of the learning process

\section{ABSTRAKSI}

Era globalisasi yang terjadi sekarang ini membutuhkan sumber daya manusia yang mampu bersaing, di sisi lain sumber daya manusia Indonesia belum memenuhi kriteria di atas. Bahkan secara kualitatif, kenyataan menunjukkan bahwa sumber daya manusia Indonesia cukup rendah dan cenderung menurun. Indikator rendahnya sumber daya manusia Indonesia ini dapat dilihat dari prestasi siswa. Permasalahan pendidikan berupa masih cukup rendahnya sumber daya manusia Indonesia merupakan tantangan berat bagi keadaan pendidikan di Indonesia. Diperlukan peningkatan mutu pendidikan Indonesia agar dihasilkan sumber daya manusia sesuai yang diharapkan, deteksi menurunnya prestasi peserta didik harus dimulai dari pendidik sebagai ujung tombak keberhasilan pendidikan. Metode ini dapat mengoptimalkan potensi intelektual, sosial dan emosional mahasiswa. Hal ini merupakan satu hal mengapa media pembelajaran sangat diperlukan dalam proses pembelajaran. Media pembelajaran merupakan salah satu komponen pembelajaran yang mempunyai peranan penting dalam proses pembelajaran. Pemanfaatan media seharusnya merupakan bagian yangharus mendapat perhatian guru sebagai fasilitator dalam setiap kegiatan pembelajaran. Olehkarena itu tiaptiap pendidik perlu mempelajari bagaimana menetapkan media pembelajaran agar dapat mengefektifkan pencapaian tujuan pembelajaran dalam proses belajar mengajar.Pada kenyataannya media pembelajaran masih sering terabaikan dengan berbagai alasan.

Kata kunci: pendidikan, iLearning, efektivitas proses pembelajaran

\section{PENDAHULUAN}


Sumber Daya Manusia (SDM) memegang peranan yang sangat penting untuk kemajuan suatu bangsa, sehingga kegiatan untuk meningkatkan potensi SDM merupakan prioritas penting yang harus diperhatikan dengan seksama. Namun jumlah SDM yang besar dan tersebar telah menjadi tantangan bagi pemerataan pendidikan di Indonesia untuk meningkatkan potensi SDM tersebut. Pendidikan Nasional bertujuan mencerdaskan kehidupan bangsa sekaligus mengembangkan kualitas sumber daya manusia khususnya generasi muda sebagai komponen bangsa secara optimal. Selain itu juga, mengupayakan perluasan dan pemerataan perolehan pendidikan yang bermutu tinggi bagi seluruh rakyat Indonesia sehingga akan tercipta manusia yang berkualitas tinggi. Sistem pembelajaran yang selama ini dilakukan yaitu sistem pembelajaran konvensional (faculty teaching), kental dengan suasana instruksional dan dirasakurang sesuai dengan dinamika perkembangan ilmu pengetahuan dan teknologi yang demikian pesat. Pada kenyataannya bahwa saat ini Indonesia memasuki era informasi yaitu suatu era yang ditandai dengan makin banyaknya medium informasi, tersebarnya informasi yang makin meluas dan seketika, serta informasi dalam berbagai bentuk yang bervariasi tersaji dalam waktu yang cepat. Dalam proses belajar mengajar, dua unsur yang amat penting adalah metode mengajar dan media pembelajaran. Kedudukan media pendidikan sebagi alat bantú mengajar ada dalam komponen metodologi, sebagai salah satu lingkungan belajar yang diatur oleh pendidik.

Dari uraian tesebut menunjukkan bahwa kehadiran media telah mempengaruhi seluruh aspek kehidupan, termasuk sistem pendidikan kita,meskipun dalam derajat yang berbeda-beda. Salah satu faktor yang ada di luar individu adalah tersedianya media pembelajaran yang memberi kemudahan bagi individu untuk mempelajari materi perkuliahan, sehingga menghasilkan belajar yang lebih baik. Sebuah metode pembelajaran sangat menentukan hasil atau output yang tercipta dari metode pembelajaran tersebut. Sumber daya manusia yang semakin hari di tuntut untuk lebih kreatif dan maju. Begitu pula yang terjadi pada Perguruan Tinggi Raharja, setiap waktu berusaha untuk meningkatkan kualitas dan kuantitas pembelajaran yang ada. Tentu saja semua itu dibutuhkan fasilitas yang memadai, oleh karena itu terciptalah sebuah metode pembelajaran yang bernama iLearning [1]. Ada beberapa aplikasi yang menjadi hal utama dalam metode iLearning ini, salah satu di antaranya adalah iBooks yang merupakan sebuah aplikasi di dalam iPad yang berbentuk seperti rak buku dimana rak tersebut dapat memuat ratusan buku-buku. Aplikasi tersebut tentunya sangatlah membantu dan menopang metode iLearning ini. Spesifikasi yang ada di dalam iBooks sangat mempengaruhi berjalannya sebuah kegiatan belajar mengajar berbasis iLearning. Namun apakah materi pembelajaran iLearning yang berupa iBooks sudah dapat tersimpan dengan baik dalam bentuk media penyimpanan keseluruhan bahan ajar, hal tersebut menentukan mutu kulitas dalam prosess pembelajaran iLearning. 


\section{PERMASALAHAN}

Pada saat ini Perguruan Tinggi Raharja sedang bersemangat mengembangkan metode pembelajaran iLearning, di dalam iBooks kita bisa mendapatkan kemudahan membaca karena di dalamnya anda dapat mengkatagorikan file yang berupa pdf atau dokumen lainya. iBooks adalah aplikasi yang sangat baik dan terbaik bagi anda yang suka membaca banyak buku, karena dengan iBooks anda bisa membaca ribuan buku bacaan anda tanpa harus membawa buku yang tebal dan banyak, dan ini lah aplikasi yang selalu di tampilkan apps store pada saat kita pertama kali membuat account apple id. Sebagian besar sistem pelayanan masih dilakukan secara face to face antara mahasiswa yang memerlukan pelayanan dan petugas pelaksana yang memberikan pelayanan [2]. Akibatnya pelayanan menjadi tidak optimal, tidak efisien, menciptakan antrian, memerlukan waktu tunggu yang lama, dan memerlukan sumber daya yang banyak .

Kata media merupakan bentuk jamak dari kata medium. Medium dapat didefinisikan sebagai perantara atau pengantar terjadinya komunikasi dari pengirim menuju penerima [3]. Media merupakan salah satu komponen komunikasi, yaitu sebagai pembawa pesan dari komunikator menuju komunikan . Berdasarkan definisi tersebut, dapat dikatakan bahwa proses pembelajaran merupakan proses komunikasi. Proses pembelajaran mengandung lima komponen komunikasi, guru (komunikator), bahan pembelajaran, media pembelajaran, siswa (komunikan), dan tujuan pembelajaran. Jadi, Media pembelajaran adalah segala sesuatu yang dapat digunakan untuk menyalurkan pesan (bahan pembelajaran), sehingga dapat merangsang perhatian, minat, pikiran, dan perasaan siswa dalam kegiatan belajar untuk mencapai tujuan belajar.Sebuah perguruan tinggi akan tertarik dan mau menggunakan iLearning jika konsep yang digunakan menghasilkan suatu sistem yang dapat memberikan fasilitas penyimpanan dalam bentuk media pembelajaran, namum apakah kumpulan berbagai bahan ajar matakuliah sudah dapat tersimpan dengan baik sebagai pendukung metode pembelajaran berbasis iLearning, seperti yang digambarkan pada Gambar 1.

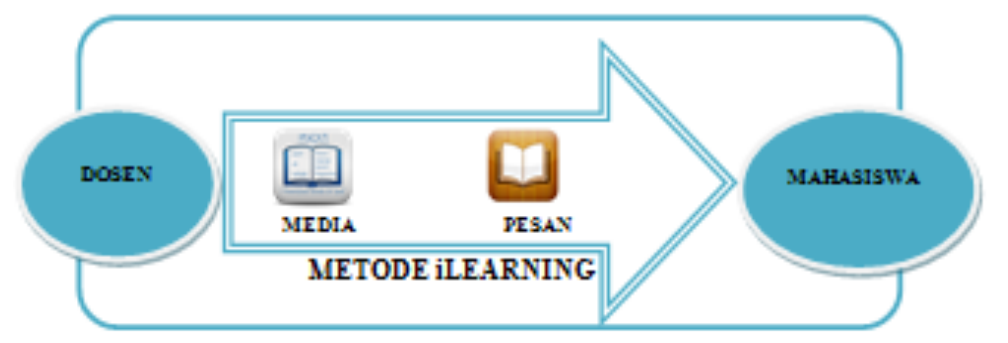

Gambar 1. Fungsi Media Penyimpanan dalam proses Pembelajaran

Dalam kegiatan interaksi antara siswa dengan lingkungan, fungsi media dapat diketahui berdasarkan adanya kelebihan media dan hambatan yang mungkin timbul dalam proses pembelajaran. Tiga kelebihan kemampuan media adalah sebagai berikut. Pertama, kemapuan fiksatif, artinya dapat menangkap, menyimpan, dan menampilkan 
kembali suatu obyek atau kejadian. Dengan kemampuan ini, obyek atau kejadian dapat digambar, dipotret, direkam, difilmkan, kemudian dapat disimpan dan pada saat diperlukan dapat ditunjukkan dan diamati kembali seperti kejadian aslinya. Kedua, kemampuan manipulatif, artinya media dapat menampilkan kembali obyek atau kejadian dengan berbagai macam perubahan (manipulasi) sesuai keperluan, misalnya diubah ukurannya, kecepatannya, warnanya, serta dapat pula diulang-ulang penyajiannya. Ketiga, kemampuan distributif, artinya media mampu menjangkau audien yang besar jumlahnya dalam satu kali penyajian secara serempak, misalnya siaran TV atau Radio. Dari penjelasan di atas, dapat dirumuskan permasalahan yang ada adalah tidak adanya media penyimpanan khusus untuk materi bahan ajar yang sudah siap berupa iBooks untuk memenuhi kebutuhan mahasiswa sebagai proses pembelajaran iLearning yaitu Bagimana merancang sebuah data storage engine didalam suatu jaringan pada sebuah aplikasi yang dapat diakses oleh banyak user.

Dalam era perkembangan iptek yang begitu pesat dewasa ini, profesionalisme dosen tidak cukup hanya dengan kemampuan membelajarkan siswa, tetapi juga harus mampu mengelola informasi dan lingkungan untuk memfasilitasi kegiatan belajar siswa [4]. Konsep lingkungan meliputi tempat belajar, metode, media, sistem penilaian, serta sarana dan prasarana yang diperlukan untuk mengemas pembelajaran dan mengatur bimbingan belajar sehingga memudahkan siswa belajar. Dampak perkembangan Iptek terhadap proses pembelajaran adalah diperkayanya sumber dan media pembelajaran, seperti buku teks, modul, overhead transparansi, film, video, televisi, slide, hypertext, web, dan sebagainya. Dosen profesional dituntut mampu memilih dan menggunakan berbagai jenis media pembelajaran yang ada di sekitarnya. Pemerolehan pengetahuan dan keterampilan, perubahan-perubahan sikap dan perilaku dapat terjadi karena interaksi antara pengalaman baru dengan pengalaman yang pernah dialami sebelumnya. Hasil belajar mahasiswa sering diawali dari pengalaman langsung, kenyataan yang ada dilingkungan kehidupan seseorang kemudian melalui benda tiruan sampai kepada lambang verbal. Pengalaman langsung akan memberikan kesan paling utuh dan paling bermakna tentang informasi dan gagasan yang terkandung dalam pengalam tersebut, sebab pengalaman tersebut melibatkan indera penglihatan, pendengaran, perasaan, penciuman dan peraba. Pandangan yang beranggapan bahwa mengajar hanya sebatas menyampaikan ilmu itu sudah layak untuk ditinggalkan karena sudah tidak sesuai lagi dengan tuntutan perkembangan zaman, belajar adalah proses perubahan perilaku. Namun demikian akan sulit melihat bagaimana proses terjadinya perubahan tingkah laku dalam diri seseorang, oleh karena perubahan tingkah laku berhubungan dengan perubahan sistem syaraf dan perubahan energi yang sulit dilihat dan diraba. Oleh karena itu, terjadinya proses perubahan tingkah laku merupaka suatu misteri, atau para ahli psikologi menamakannya sebagai kotak hitam (Black Box). 


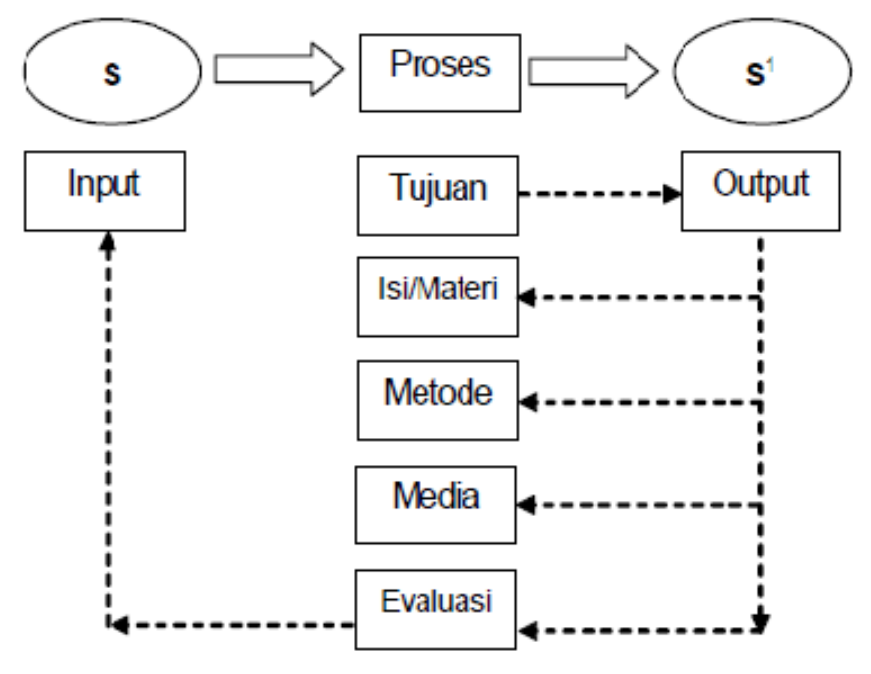

Gambar 2. Komponen Proses Pembelajaran

Dari bagan diatas dapat dilihat bahwa sebagai suatu sistem, proses pembelajaran terdiri atas beberapa komponen yaang satu sama lain saling berinteraksi dan berinterelasi. Komponen-komponen tersebut adalah tujuan, materi pelajaran, strategi, atau, metode pembelajaran, media dan evaluasi. Kelima komponen tersebut yang perlu diusahakan untuk selalu ada inovasi agar proses pembelajaran dapat menghasilkan perubahan sebagaimana diharapkan. Dalam pelaksanaan proses belajar mengajar, dua hal yang teramat penting adalah metode mengajar yang digunakan serta dukungan dari media pengajaran. Kedua aspek tersebut saling terkait datu sama lain. Pemilihan metode pengajaran sangat mempeengaruhi media pengajaran yang digunakan. Hal tersebut berarti bahwa pemilihan media pengajaran harus didasarkan pada metode pengajaran yang digunakan. Media pengajaran yang digunakan sebagai alat bantu dalam peroses belajar mengajar berfungsi untuk membangkitkan keinginan dan minat baru, membangkitkan motivasi dan rangsangan kegiatan belajar dan bahkan membawa pengaruh psikologis terhadap siswa. Dengan demikian penggunaan media pengajaran dapat membawa manfaat besar terhasap keberhasilan pelaksanaan kegiatan belajar mengajar di kelas. Semakin sadarnya orang akan pentingnya media yang membantu pembelajaran sudah mulai dirasakan. Pengelolaan alat bantu pembelajaran sudah sangat dibutuhkan. Metamorfosis dari perpustakaan yang menekankan pada penyediaan meda cetak, menjadi penyediaan-permintaan dan pemberian layanan secara multi sensori dari beragamnya kemampuan individu untuk memberikan informasi, menjadikan pelayanan yang diberikan mutlak wajib bervariatif dan secara luas. Selain itu,dengan semakin meluasnya kemajuan di bidang komunikasi dan teknologi, serta diketemukannya dinamika proses belajar, maka pelaksanaan kegiatan pendidikan dan pengajaran semakin menuntut dan memperoleh media pendidikan yang bervariasi secara luas pula. Karena memang belajar adalah proses internal dalam diri manusia maka dosen bukanlah merupakan satu-satunya sumber belajar, namun merupakan salah satu komponen dari sumber belajar yang disebut orang. AECT (Associationfor Educational Communication and Technology) membedakan enam jenis sumber belajar yang dapat digunakan dalam proses belajar, yaitu : 
1.Pesan; didalamnya mencakup kurikulum (GBPP) dan mata pelajaran.

2.Orang; didalamnya mencakup guru, orang tua, tenaga ahli, dan sebagainya.

3. Bahan;merupakan suatu format yang digunakan untuk menyimpan pesan pembelajaran, seperti buku paket, buku teks, modul, program video, film, OHT (Over Head Transparency), program slide, alat peraga dan sebagainya (biasa disebut software).

4. Alat; yang dimaksud di sini adalah sarana (piranti, hardware) untuk menyajikan bahan pada butir 3 di atas. Di dalamnya mencakup proyektor OHP, slide, film tape recorder, dan sebagainya.

5. Teknik; yang dimaksud adalah cara (prosedur) yang digunakan orang dalam membeikan pembelajaran guna tercapai tujuan pembelajaran. Di dalamnya mencakup ceramah,permainan/simulasi, tanya jawab, sosiodrama (roleplay), dan sebagainya.

6. Latar (setting) atau lingkungan; termasuk didalamnya adalah pengaturan ruang, pencahayaan, dan sebagainya.

\section{LITERATURE REVIEW}

Dalam upaya perlu dilakukan studi pustaka sebagai salah satu dari penerapan metode penelitian yang akan dilakukan. Diantaranya adalah mengidentifikasikan kesenjangan (identify gaps), menghindari pembuatan ulang (reinventing the wheel), mengidentifikasikan metode yang pernah dilakukan, serta mengetahui orang lain yang spesialisasi dan area penelitian yang sama dibidang ini. Beberapa Literature Review tersebut adalah sebagai berikut :

1. Penelitian ini dilakukan oleh Gene Backlin dari tahun 2010 berjudul "Professional iPhone and iPad Application Development". Penelitian ini dilakukan dengan kebutuhan untuk membuat aplikasi top-notch untuk iPhone dan iPad Developers menuntut panduan lanjutan untuk menggunakan versi paling terakhir dari iPhone dan iPad SDK untuk mengembangkan aplikasi-dan buku ini menjawab bahwa panggilan. Dilengkapi lebih dari dua puluh aplikasi yang lengkap dan dirancang untuk menciptakan kembali, dibangun kembali, dan digunakan kembali oleh pengembang profesional, sumber ini menggali dunia semakin populer pengembangan aplikasi dan menyajikan panduan langkah-demi-langkah untuk membuat aplikasi yang superior untuk iPhone dan iPad. Alat pengembang banyak dan belajar bagaimana menggunakannya. Dengan cakupan versi terbaru dari iPhone dan SDK iPad dan jumlah aplikasi mandiri, buku ini akan menjadi luar biasa pergiuntuk referensi di masa depan. Dari Back Cover Membuat, membangun, dan menggunakan kembali aplikasi dengan SDK iPhone. Pengembang sedang mencari sumber canggih yang membawa mereka melalui apa yang sekarang menjadi pasar 
untuk iPhone serta pasar baru lahir untuk buku-iPad memenuhi bahwa permintaan ini. Profesional iPhone dan iPad [5].

2. Penelitian yang dilakukan oleh Matthew Young Kim di Kennesaw State University Kennesaw, GA, USA. Pada tahun 2011 dengan judul "Simulation Study of eLearning Classroom using iPads Based on Wireless LAN with IEEE 802.11b" menyajikan studi simulasi kelas e-Learning menggunakan iPad sebagai perangkat mobile berbasis pada LAN nirkabel dengan protokol IEEE 802.11b. Selain itu, makalah ini menyajikan sebuah studi simulasi apakah IEEE $802.11 \mathrm{~b}$ dapat mendukung hingga 25 iPads dari kelas e-Learning tanpa masalah keadilan pada Wireless LAN bersama. Simulasi dilakukan dengan OPNET IT Guru Academic Edition 9.1 [6].

3. Penelitian ini dilakukan oleh Dr. Rory Lewis berjudul "iPhone and iPad Apps for Absolute Beginners" tahun 2010. Penelitian ini membahas tentang bagaimana Anda membangun sebuah aplikasi untuk iPhone dan iPad? Apakah tidak Anda perlu menghabiskan tahun-tahun belajar bahasa pemrograman yang rumit? Bagaimana Objective-C, Kakao Touch, dan SDK? Jawabannya adalah bahwa Anda tidak perlu mengetahui hal-hal itu. Siapa saja bisa mulai membangun aplikasi sederhana untuk iPhone dan iPad, dan buku ini akan menunjukkan kepada Anda bagaimana caranya [7].

4. Penelitian yang dilakukan oleh Siti Mawadah berjudul "iBooks Standardisation And Good Practice For Effective Education Methods In Support Of iLearning”. Melakukan standarisasi iBooks yang meliputi Soal, Quiz, Tutorial, Gambar, Tabel, Internal link, Animasi, Video, Music, Graphic, Kesimpulan di setiap pertemuan, Syllabus, PO, Diagram, Table of Contents, Photo, Formula atau rumus, Algoritma, Link to email dan Link external. Saat ini penerapan standarisasi sebuah iBooks belum mencapai seluruh elemen atau content dalam perancangan sebuah Good iBooks [8].

5. Penelitian yang dilakukan oleh Sukriya dari ITS (Institut Teknologi Sepuluh Nopember) tahun 2009 sebagai bentuk Skripsi dengan judul "Perancangan Dan Pembuatan Perangkat Lunak E-Learning Berbasis .Net Menggunakan Teknologi Asp.Net 3.5 Dan Ajax Dengan Partial Rendering Untuk Studi Kasus Scored Online Test". Hasil pembuatan Tugas Akhir ini adalah ekplorasi teknologi baru Ajax Asp.Net serta pemanfaatannya dengan menggunakan studi kasus pembuatan perangkat lunak e-learning dengan scored online test. E-learning membawa pengaruh terjadinya proses transformasi pendidikan konvensional ke dalam bentuk digital, baik secara isi dan sistemnya. Begitu juga untuk mendapatkan feedback evaluasi pembelajaran secara cepat, tes online menjadi suatu alternatif untuk mendapatkan hasil yang optimal dengan pelaksanaan tes yang dapat dilakukan tanpa terhalang waktu dan tempat. Aplikasi yang mendukung hal ini biasanya berbasis web yang interaktif dan dinamik. Ajax Asp.Net 3.5 merupakan salah satu framework Ajax untuk Asp.Net [9]. 
6. Penelitian yang dilakukan oleh Reni Mulyani berjudul "Audio Visual One Of The Teaching Resources On iLearning” Metode pembelajaran iLearning menggunakan media audio visual, serta ditunjang dengan fasilitas iPad yang didalamnya terdapat aplikasi - aplikasi yang berhubungan dengan media audio visual seperti tutorial, gambar, animasi, music, video. Media audio visual dalam iLearning merupakan media yang sangat tepat untuk meningkatkan minat belajar mahasiswa. Pembelajaran lebih cepat ditangkap serta durasi informasi lebih lama diingat karena melibatkan dua sensor indera sekaligus yaitu audio visual dan visual, hal ini berhubungan dengan fungsi kerja otak manusia [10].

7. Penelitian yang dilakukan oleh Danny Wiliam Wongso dari Bina Nusantara tahun 2008 sebagai bentuk Skripsi dengan judul "Analisa dan Perancangan Piranti Lunak Pembangkit Soal Ujian Secara Online dengan menerapkan AJAX”. Pada tugas akhir ini penulis bertujuan untuk mengidentifikasi kebutuhan Universitas Bina Nusantara yang berkaitan dengan persediaan soal ujian, menganalisis dan merancang database, serta membuat aplikasi pembangkit soal ujian. Manfaatnya adalah untuk mendukung kemudahan proses penyediaan soal ujian sesuai Satuan Acara Perkuliahan (SAP) [11].

8. Penelitian yang dilakukan oleh Qory Oktisa Aulia berjudul "Prototype dan Implementasi Metodologi Pembelajaran iLearning Pada Matakuliah Sistem Basis Data". Mengoptimalkan iBooks untuk menunjang iLearning khususnya pada matakuliah sistem basis data. Menambahkan suatu fungsi (Quiz) disetiap akhir pertemuan, guna memudahkan dalam pelaksanaan evaluasi pembelajaran pada matakuliah Sistem Basis Data [12].

Dari delapan literature review yang ada, telah banyak penelitian mengenai sistem pembelajaran atau learning style. Namun dapat disimpulkan pula bahwa belum ada peneliti yang secara khusus membahas atau mengatasi masalah mengenai media penyimpanan bahan ajar untuk materi perkuliahan yang dapat diakses dan tersimpan otomatis kedalam aplikasi iBooks pada iPad. Kita membutuhkan perubahan metode pembelajaran yang dapat menciptakan suasana kelas serta membuat para mahasiswa lebih bersemangat dan merasa senang bukanlah hal yang mudah. Karena mahasiswa mudah sekali merasa jenuh. Itulah alasan mengapa Perguruan Tinggi Raharja menciptakan iLearning sebagai terobosan baru. Dengan konsep yang sama namun lebih modern dan berkembang menjadikan iLearning sebagai andalan untuk Perguruan Tinggi Raharja.

\section{PEMECAHAN MASALAH}

Untuk mengatasi berbagai masalah diatas, maka diperlukan proses yang cepat dan efisien dalam mengakses seluruh data yang banyak dan tidak teratur di dalam media penyimpanan yang berupa sebuah aplikasi, terlebih untuk suatu sistem informasi yang akurat. Kecanggihan iPad yang kita manfaatkan sebagai media penunjang berjalannya iLearning di perguruan tinggi Raharja. Kini belajar bukan hanya didalam kelas, bukan 
hanya di atas kertas, namun dengan iLearning kita menunjukan bahwa kita bisa belajar dimanapun dan kapanpun. Aktifitas apapun adalah belajar. Saat kita bermain dengan jari dan iPad kita, saat itulah kita sedang belajar. Menjelajahi dunia maya dengan mencari informasi yang sangat kaya dan berkualitas tentunya itulah belajar yang sesungguhnya. Bila kita mendefinisikan belajar adalah membaca, menulis, tentunya itulah metode pembelajaran yang kuno. Kita butuh perubahan karena kini dunia sudah begitu maju dan akan selalu membutuhkan perkembangan dari berbagai sisi. iDINI (integrated Download Ibooks iN Ipad) merupakan media pendukung pembelajaran iLearning yang berupa sebuagh aplikasi, penggunaan aplikasi iDINI sebagai media penyimpanan bahan ajar materi perkuliahan dapat meningkatkan aktivitas siswa dalam pembelajaran iLearning dan siswa telah termotivasi dalam proses pembelajaran, diharapkan aktivitas serta prestasi belajar mereka terhadap pembelajaran dapat meningkat. Fungsi dan manfaat media pengajaran juga dikemuakkan oleh Sudjana (2002), bahwa "dengan penggunaan media pengajaran dapat mempertinggi pembelajaran siswa dalam pengajaran yang pada gilirannya diharapkan dpat mempertinggi hasil belajar yang dicapainya. Penggunaan media pengajaran pada saat terjadinya pembelajaran dalam kelas diharapkan dapat mempertinggi minat dan perhatian siswa dalam mengikuti pembelajaran yang sedang berlangsung. Hal tersebut dapat mempertinggi motivasi siswa untuk mengikuti proses belajar mengajar. Selain hal tersebut dengan penggunaan media pengajaran maka siswa dapat melihat secara langsung, tidak hanya dengan katakata sehingga diharapkan siswa dapat lebih mudah memahami apa yang disampaikan oleh dosen dalam kelas. Sedangkan menurut Levie dan Lentz khususnya media visual adalah: (1) fungsi atensi yaitu menarik dan mengarahkan perhatian siswa untuk berkonsentrasi kepada isi pengajaran yang berkaitan dengan makna visual yang ditampilkan, (2) fungsi afektif yang dapat mengubah emosi dan sikap siswa, (3) fungsi kognitif yang memperlancar pencapaian tujuan untuk memahami dan mengingat informasi atau pesan yang terkandung dalam gambar, dan (4) kompensatoris yaitu memberikan konteks untuk memahami teks dan memabantu siswa yang lemah dalam membaca dan mengorganisasikan informasi. Dari keempat fungsi dan manfaat media pembelajaran tersebut, maka dapat diketahui bahwa sesungguhnya penggunaan media pengajaran dapat meningkatkan kualitas hasil belajar mengajr yang diperoleh oleh siswa karena ketiga komponen kognitif, afektif dan psikomotorik dalam pembelajaran dapat dipacu. Hal tersebut daat memepertinggi hasil dan prestasi belajar siswa dan sekaligus dapat mendukung dan mendorong siswa yang memeiliki kemampuan yang terbatas dalam menerima informasi dan pesan dalam pembelajaran yang berlansung. Efektifitas penggunaan media terhadap proses belajar bengajar tersebut terjadi karena dalam proses pengugunaannya siswa dilibatkan tidak hanya dalam benak ataupun mentalnya saja akan tetapi dapat memperhatikan dan menyaksikan secara langung informasi yag disampaika dalampembelajaran tersebut.

Proses pembelajaran merupakan proses komunikasi dan berlangsung dalam suatu sistem, maka media pembelajaran menempati posisi yang cukup penting sebagai salah satu komponen sistem pembelajaran. Tanpa media, komunikasi tidak akan terjadi dan proses pembelajaran sebagai proses komunikasi juga tidak akan bisa berlangsung secara optimal. Fungsi media dalam proses pembelajaran adalah sebagai berikut : 
1. Menyaksikan benda yang ada atau peristiwa yang terjadi pada masa lampau. Dengan perantaraan gambar, potret, slide, film, video, atau media yang lain, siswa dapat memperoleh gambaran yang nyata tentang benda/peristiwa sejarah.

2. Mengamati benda/peristiwa yang sukar dikunjungi, baik karena jaraknya jauh, berbahaya, atau terlarang. Misalnya, video tentang kehidupan harimau di hutan, keadaan dan kesibukan di pusat reaktor nuklir, dan sebagainya.

3. Memperoleh gambaran yang jelas tentang benda/hal-hal yang sukar diamati secara langsung karena ukurannya yang tidak memungkinkan, baik karena terlalu besar atauterlalu kecil. Misalnya dengan perantaraan paket siswa dapat memperoleh gambaran yang jelas tentang bendungan dan kompleks pembangkit listrik, dengan slide dan film siswa memperoleh gambaran tentang bakteri, amuba, dan sebaginya.

4. Mendengar suara yang sukar ditangkap dengan telinga secara langsung. Misalnya, rekaman suara denyut jantung dan sebagainya.

5. Mengamati dengan teliti binatang-binatang yang sukar diamati secara langsung karena sukar ditangkap. Dengan bantuan gambar, potret, slide, film atau video siswa dapat mengamati berbagai macam serangga, burung hantu, kelelawar, dan sebagainya.

6. Mengamati peristiwa-peristiwa yang jarang terjadi atau berbahaya untuk didekati.Dengan slide, film, atau video siswa dapat mengamati pelangi, gunung meletus, pertempuran, dan sebagainya.

Dengan demikian, apabila pembelajaran memanfaatkan lingkungan sebagai alat/ media pembelajaran dalam proses belajar mengajar maka peserta didik akan memiliki pemahaman yang bagus tentang materi yang didapatkan, sehingga besar kemunkinan dengan memperhatikan alat atau media pengajaran itu tujuan pembelajaran akan tercapai dengan efektif dan efisien. Variasi dalam pembelajaran dengan menjadikan lingkungan sebagai media belajar menyenangakan akan mendukung pelajaran yang tidak membosankan bahkan menjadikan belajar semakin efektif. Diperlukan sebuah media tambahan untuk penyimpanan bahan ajar materi perkuliahan pembelajaran iLearning di Perguruan Tinggi Raharja dengan merancang sebuah aplikasi atau media penyimpana yang digunakan oleh dosen dan mahasiswa dalam kegiatan belajar mengajar. Aplikasi yang dirancang adalah iDINI (integrated Download Ibooks iN Ipad) aplikasi ini merupakan aplikasi penyimpanan berbagai bahan ajar materi perkuliahan dalam bentuk file epub yang digunakan untuk menyampaikan materi berupa yang dapat dilihat dalam bentuk (visual) dan suara (audio). iDINI ini sendiri adalah sebuah aplikasi atau media penunjang sistem pembelajaran iLearning dimana didalam aplikasi ini terdapat kumpulan bahan ajar materi perkuliahan, fasilitas download, fasilitas upload file untuk dosen, fasilitas tombol like dan history jumlah pengunjung sesuai nama matakuliah. Berikut adalah penjelasan dari beberapa feature unggulan yang ada pada apkilasi iDINI :

\section{1. iLearning}

Sistem pembelajaran konvensional yang diterapkan secara modern. Oleh karena iLearning dikemas dengan sedemikian rupa dengan content - content pendukung. Sebagai penunjang untuk kegiatan belajar mengajar yang modern iLearning ialah mengintergrasikan teknologi untuk belajar, bermain, berdoa, dan bekerja. 


\section{Download}

Adalah proses transmisi sebuah file dari sebuah sistem computer ke sistem komputer yang lainnya. Dari internet, user yang melakukan proses download adalah proses dimana seorang user meminta / request sebuah file dari sebuah komputer lain (web site,server atau yang lainnya) dan menerimanya. Dengan kata lain, download adalah transmisi data dari internet ke komputer client/pemakai.

\section{Upload}

Adalah proses transmisi sebuah file dari sebuah sistem komputer ke sistem komputer yang lainnya dengan arah yang berkebalikan dengan download. Dari internet, user yang melakukan proses upload adalah proses dimana user mengirimkan file ke komputer lain yang memintanya. User yang men-share gambar,foto dengan yang user yang lainnya di bulletin board sytem (BBS), mengupload file ke BBS. File Transfer Protocol (FTP) adalah contoh Internet protokol untuk downloading and uploading files.

Dalam aplikasi iDINI terdapat berbagai macam feature pendukung, yaitu adanya fasilitas untuk melakukan download file materi bahan ajar yang sudah dapat tersimpan otomatis langsung pada iBooks dalam iPad, selain itu juga dapat memberikan informasi dari setiap matakuliah yang sudah disesuaikan dengan kurikulum iLearning secara akademik. Kemudian adanya fasilitas dosen untuk login pada saat ingin melakukan upload file bahan ajar materi yang baru, dalam aplikasi iDINI ini kita dapat melihat history dari view berapa banyak pengunjung pada halaman masing - masing matakuliah serta difasilitasi dengan tombol like. Secara umum manfaat media pembelajaran adalah memperlancar interaksi antara dosen dengan mahasiswa sehingga kegiatan pembelajaran lebih efektif dan efisien. Sedangkan secara lebih khusus manfaat media pembelajaran adalah:

1. Penyampaian materi pembelajaran dapat diseragamkan

2. Proses pembelajaran menjadi lebih jelas dan menarik

3. Proses pembelajaran menjadi lebih interaktif

4. Efisiensi dalam waktu dan tenaga

5. Meningkatkan kualitas hasil belajar siswa

6. Media memungkinkan proses belajar dapat dilakukan di mana saja dan kapan saja

7. Media dapat menumbuhkan sikap positif siswa terhadap materi dan proses belajar

8. Mengubah peran dosen ke arah yang lebih positif dan produktif

Dari penjelasan diatas, disimpulkan bahwa fungsi dari media pembelajaran yaitu media yang mampu menampilkan serangkaian peristiwa secara nyata terjadi dalam waktu lama dan dapat disajikan dalam waktu singkat dan suatu peristiwa yang digambarkan harus mampu mentransfer keadaan sebenarnya, sehingga tidak menimbulkan adanya verbalisme. Media penyimpanan bahan ajar tersebut sangatlah dibutuhkan, selain sebagai penunjang pembelajaran iLearning juga dapat difungsikan dengan baik agar keseluruhan bahan ajar materi perkuliahan dapat tersimpan dengan baik untuk menghindari kemungkinan hilangnya data-data yang tidak terorganisir dengan baik. Untuk dapat engakses aplikasi iDINI ini. Dalam hal aktivitas penggunaan iBooks, telah dilakukan observasi pengamatan secara langsung dengan menyebarkan quisioner pada kelas iLearning yang aktif seperti tampak pada ilustrasi berikut : 


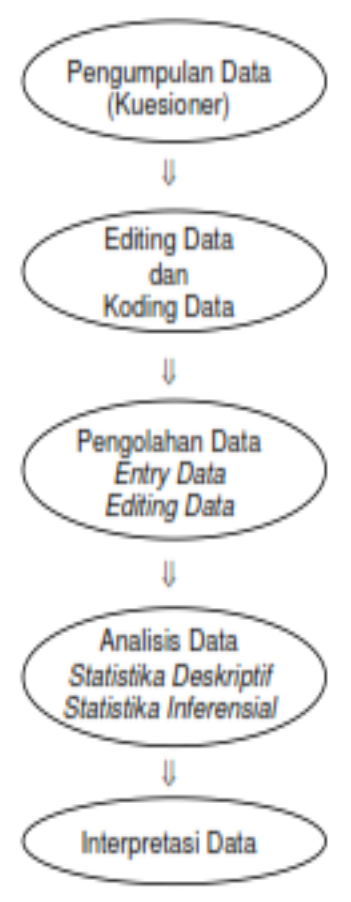

Gambar 3. Ilustrasi Pengolahan dan Analisi Data

1. Melakukan obesravsi secara langsung untuk mengamati kinerja dosen, suasana kelas, penggunaan iPad $+i B o o k s$, dan mengamati mahasiswa/i yang pada saat itu sedang melakukan proses pembelajaran dengan menggunakan metode iLearnig.
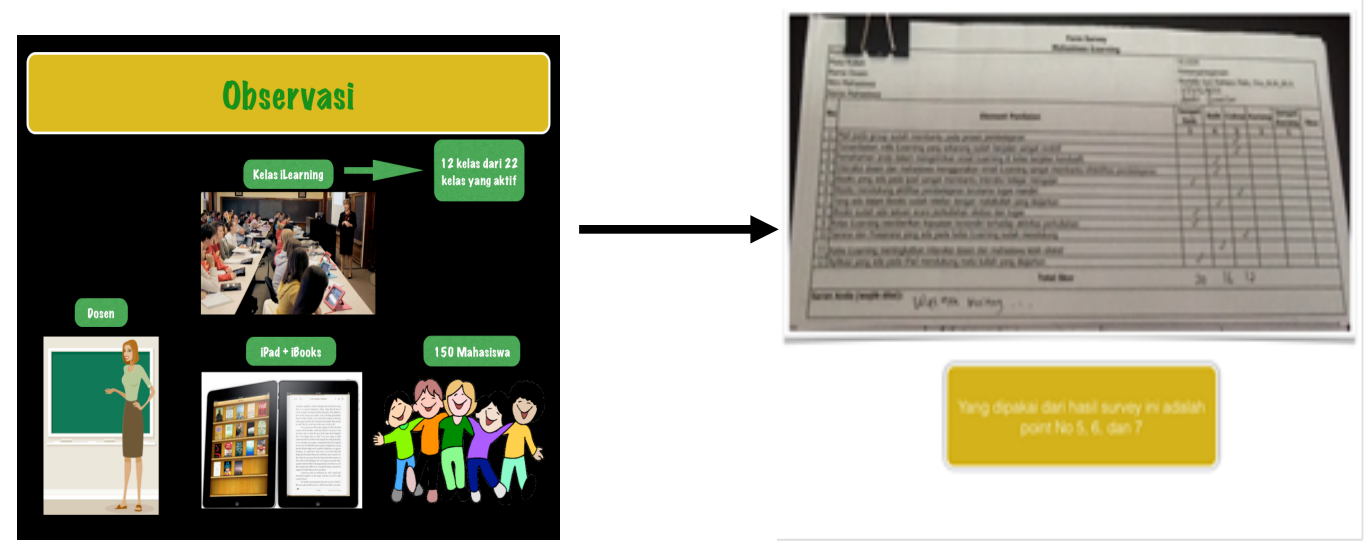

Yang dipakai dari hasil survey ini adalah point No 5, 6 dan 7 yaitu :

a.iBooks yang ada di dalam iPad sangat membantu interaksi belajar mengajar.

b. iBooks mendukung aktifitas pembelajaran terutama tugas mandiri.

c. Yang ada dalam iBooks sudah relevan dengan matakuliah yang diajarkan.

2. Melakukan pengolahan data dari 150 lembar quisioner yang disebarkan pada tiap masing-masing kelas, perhitungan dilakukan pada setiap lembar quisioner kemudian dikalikan point penilaian, setalah itu nilainya ditotalkan agar dapat terlihat nilai akhir dari hasil keseluruhan untuk melakukan analisa hasilnya. 

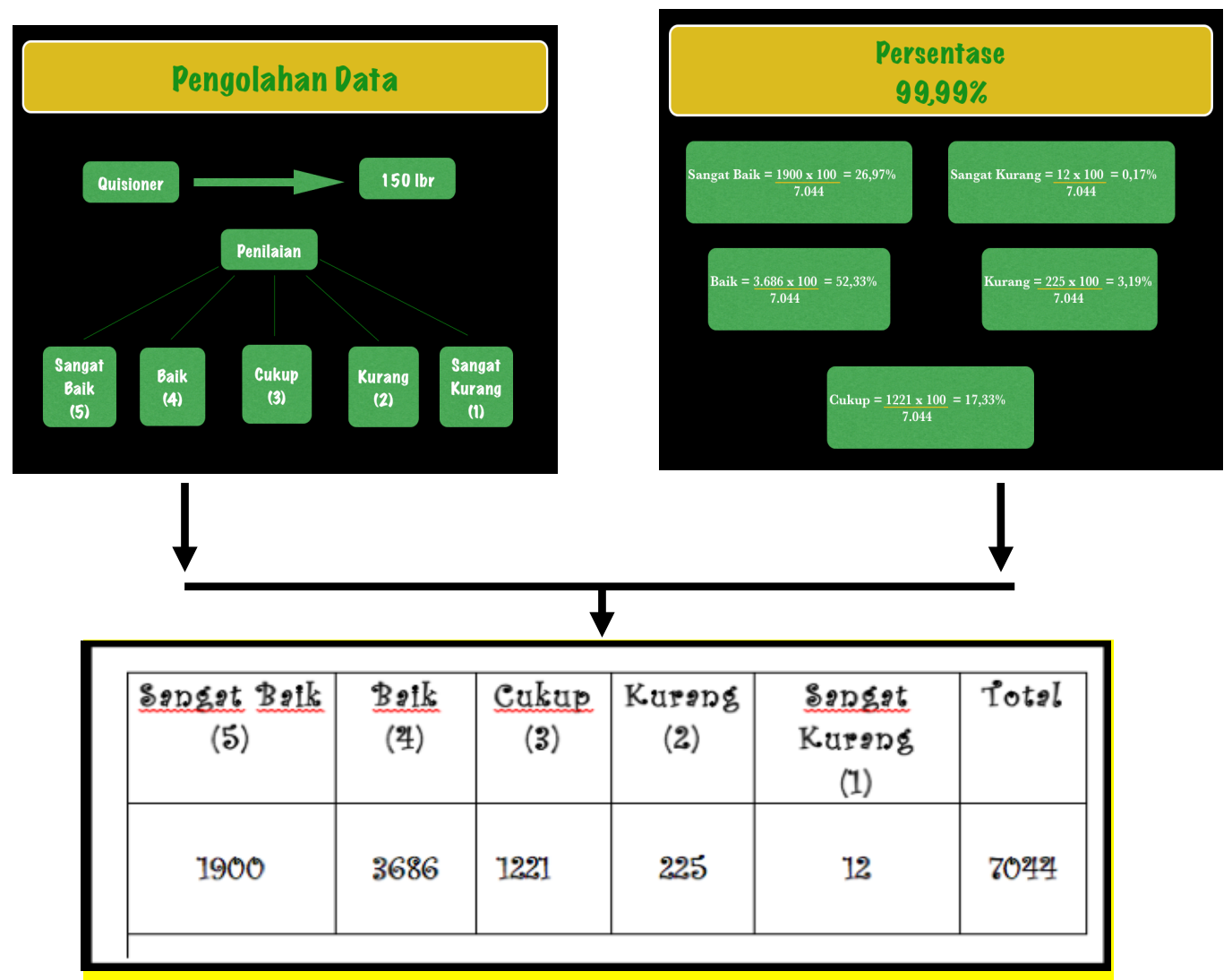

3. Hasil dari perhitungan pengolahan data quisioner, kemudian dibuat dalam bentuk Diagram Pie, Diagram Statistik dan juga Graphic Statistik yang dapat dilihat pada gambat dibawah ini.

\section{Patokan Perhitungan}
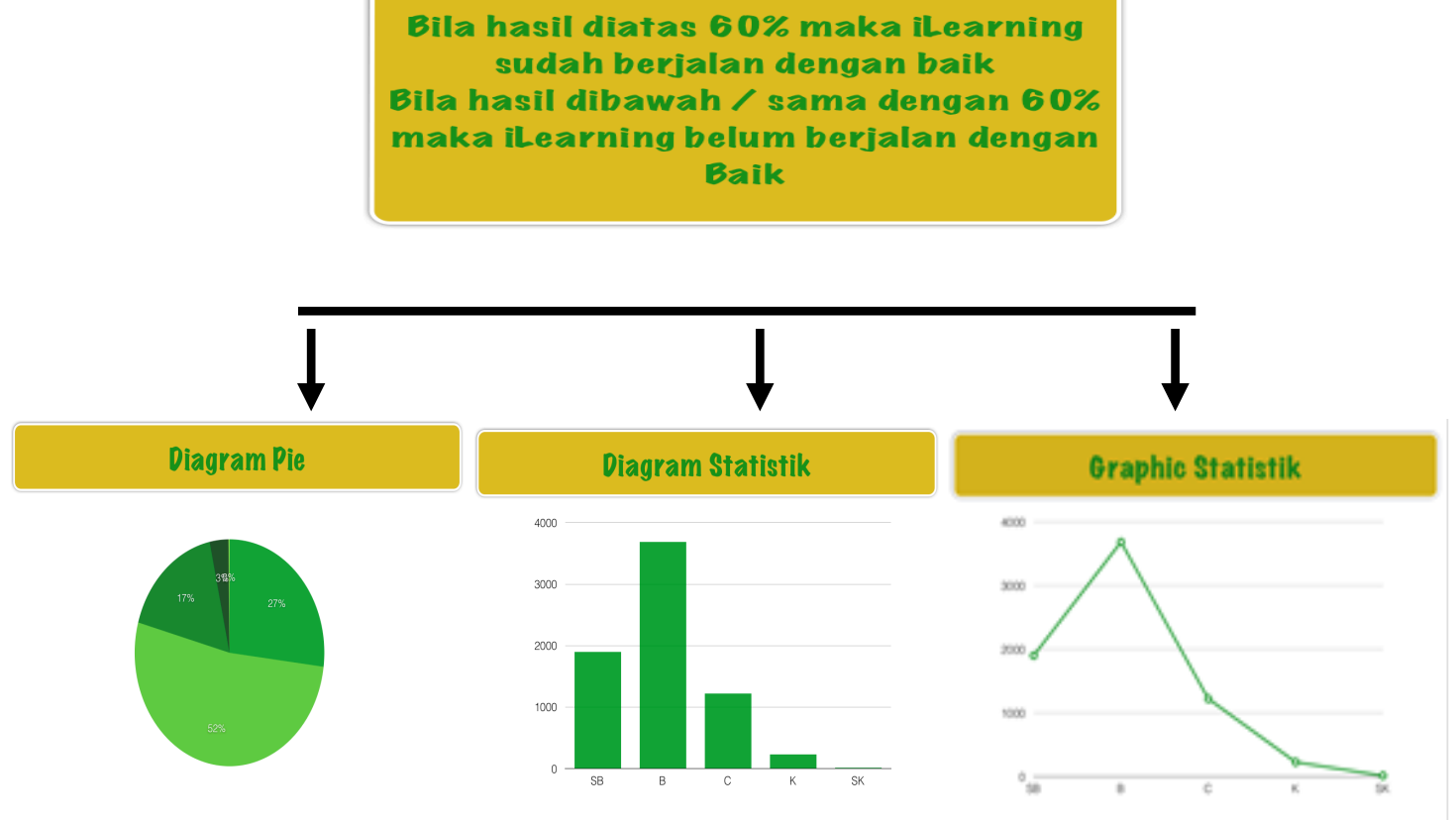
Berdasarkan hasil survey yang sudah dijalani selama 2 minggu berturut - turut, dari total mahasiswa iLearning yang ada sejumlah 255 mahasiswa. Maka diambil sample sebanyak 150 mahasiswa, yang terdiri dari 12 content pertanyaan dengan rincian skor 5, 4, 3, 2, 1. Kemudian total skor dari 150 mahasiswa yaitu 7.044, dengan demikian dapat disimpulkan bahwa iLearning yang berjalan saat ini dikatakan BAIK $(52,33 \%)$.

\section{Listing Program}

iDINI merupakan sebuah aplikasi media penyimpanan untuk kumpulan berbagai macam bahan ajar materi perkuliahan sebagai pendukung pebelajaran iLearning, sehingga listing program yang akan ditampilkan yaitu listing program download materi bahan ajar . Berikut listing programnya :

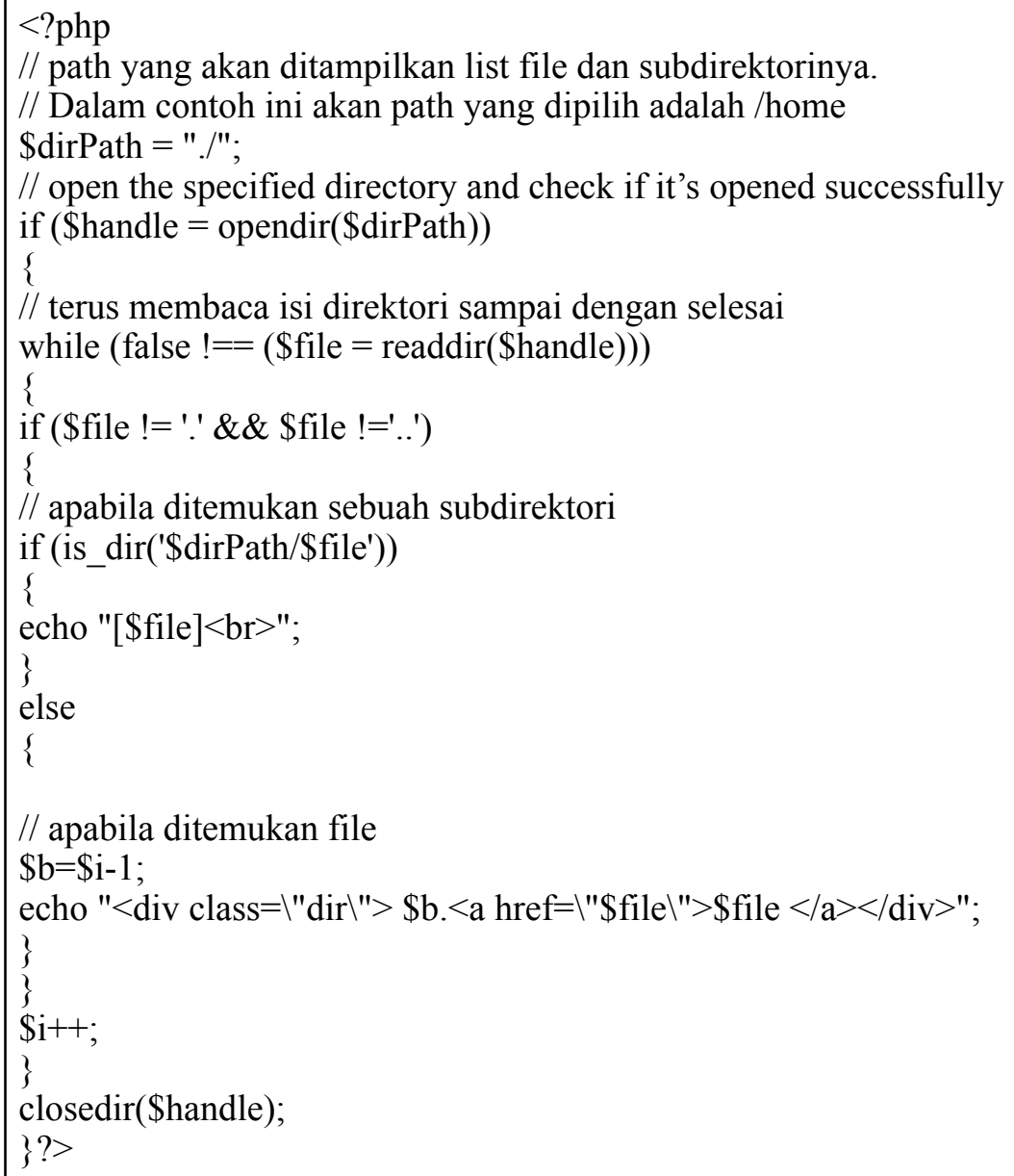


Gambar 4. Listing Program Download Materi Bahan Ajar Perkuliahan

\section{IMPLEMENTASI}

Tampilan aplikasi (application) iDINI memiliki berbagai macam fiture yang dapat digunakan oleh mahasiswa maupun dosen yang terdiri dari :

a. Tampilan Utama Aplikasi iDINI

Logo aplikasi tersebut sudah dalam bentuk icon apps for iPad

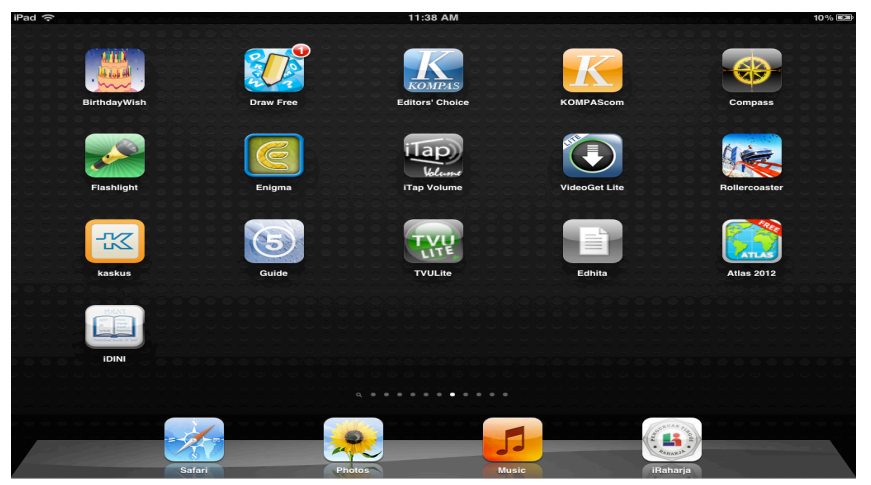

Gambar 5. Logo Aplikasi iDINI

b. Tampilan Searching Menu Utama

Pada tampilan ini kita bisa melihat keseluruhan materi perkuliahan dengan melakukan searching berdasarkan nama dosen maupun judul matakuliah.

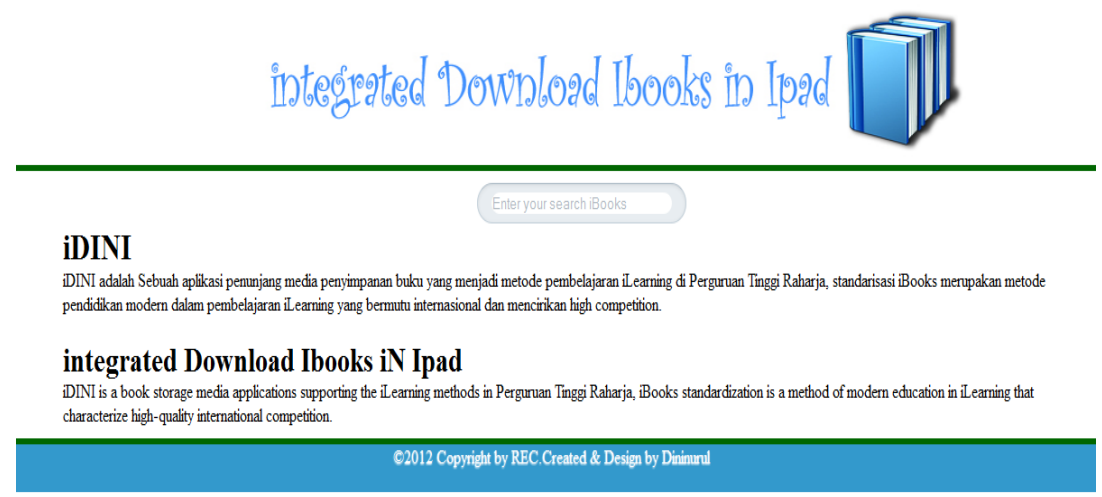

Gambar 6. Tampilan Searching Menu Utama

c. Tampilan Kumpulan Matakuliah

Tampilan ini memberikan pilihan berbagai macam bahan ajar materi perkuliahan yang dapat langsung di download. 


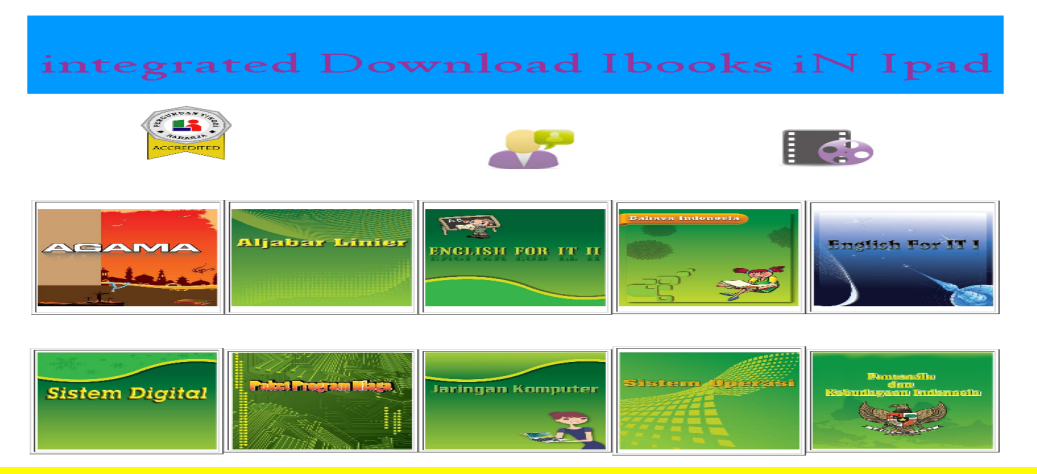

Gambar 7. Tampilan Kumpulan Bahan Ajar

d. Tampilan Untuk Download Materi Perkuliahan

Pada saat akan melakukan download materi, kita dapat melihat rincian informasi secara akademik yang sudah disesuaikan dengan kurikulum iLearning dan juga terdapat informasi nama dosen pengajar dari matakuliah tersebut.

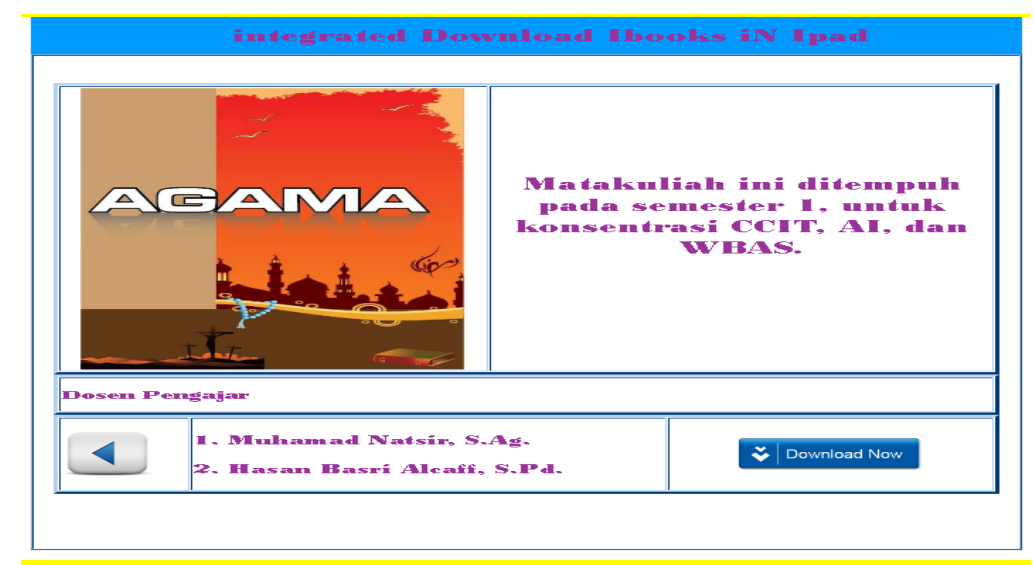

Gambar 8. Tampilan Untuk Download Materi Perkuliahan

Pada tampilan dibawah ini terlihat keberhasilan saat melakukan download maka terdapat pilihan open ini ibooks dan open in pages.

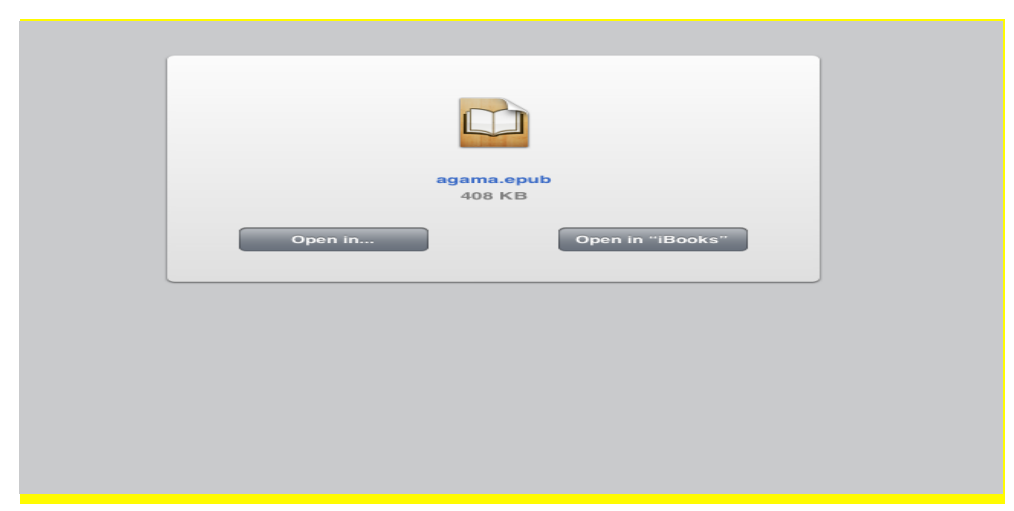

Gambar 9. Tampilan Pada Saat Open in iBooks 
Sedangkan untuk tampilan berikutnya adalah, sudah tersimpan otomatis ke dalam rak buku pada aplikasi iBooks file yang sudah di download tersebut.

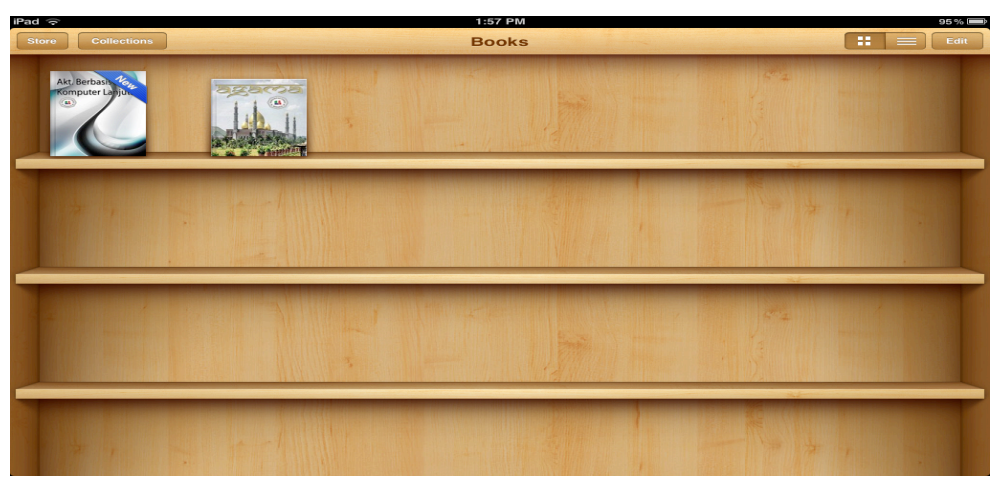

Gambar 10. Tampilan Tersimpan di Rak Buku Pada Media iBooks

e. Tampilan Untuk Login Dosen

Tampilan ini adalah akses utama dosen pada saat ingin melakukan update bahan ajar terbaru, pada saat login dosen harus memasukan username dan password yang sudah diberikan oleh admin.

\section{Panel Lecture iDINI}

\section{User Name}

Password

\section{Login}

Gambar 11. Tampilan Login Akses Dosen

\section{INPUT FILE MATERI PERKULIAHAN}

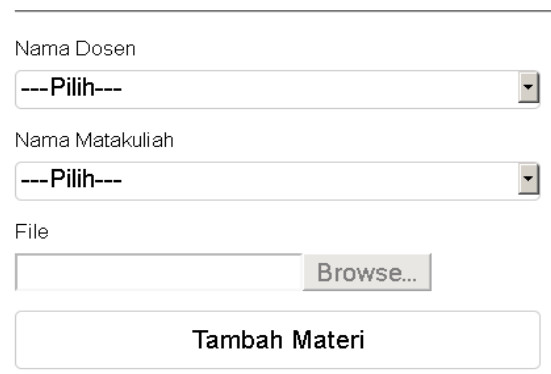

Warning: Pastikan Akses internet kencang untuk upioad file besa. 


\section{Gambar 12. Tampilan Untuk Upload File Materi Perkuliahan}

Tampilan ini berfungsi untuk memberikan akses setiap dosen iLearning dalam melakukan upload file bahan ajar materi perkuliahan, agar dapat melakukan update materi setiap ada perubahan dari masing-masing dosen pengajar. Dimana dalam fasilitas ini dapat memudahkan kinerja dosen dalam hal memberikan materi bahan ajar terbaru selain itu juga dapat memberikan kemudahan bagi mahasiswa untuk memperoleh dan mendapatkan informasi mengenai materi perkuliahan yang up to date setiap harinya.

f. Tampilan flowchart aplikasi iDINI (integrated Download Ibooks iN Ipad)

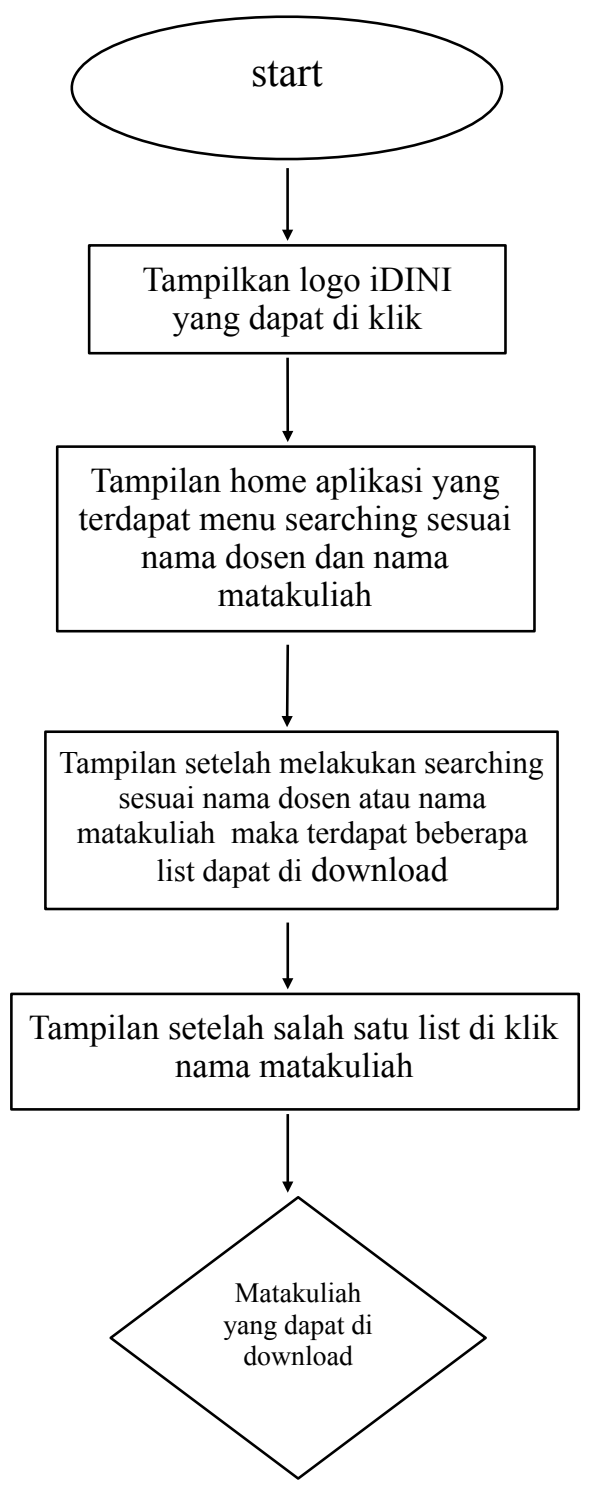




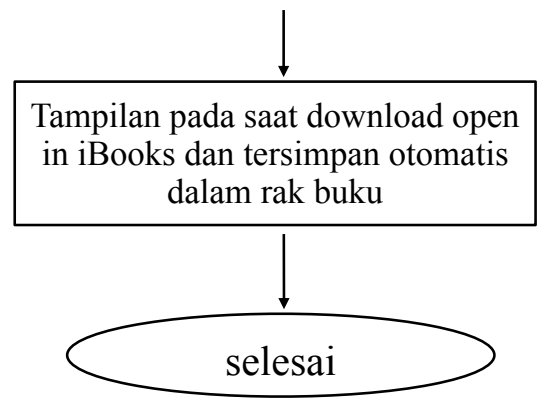

Gambar 13. Alur Program Berjalan Selesai dijalankan

Kelebihan

Dengan aplikasi ini dosen dan mahasiswa dapat memaksimalkan sistem pembelajaran iLearning didalam kelas sehingga belajar lebih efektif, efisiensi dan menyenagkan sesuai konsep iLearning. Beberapa kelebihan dari aplikasi iDINI ini adalah sebagai berikut :

1. Mahasiswa dapat melakukan download bahan ajar materi perkuliahan.

2. Dosen dapat melakukan upload file bahan ajar materi perkuliahan, sehingga materi dapat selalu up to date dalam setiap pembelajaran berlangsung.

3. Terdapat content like dan history pengunjung pada setiap rincian halaman pada setiap nama matakuliah, sehingga dapat memotivasi dosen untuk terus memperbaharui materi bahan ajar yang lebih baik untuk digunakan oleh mahasiswa.

4. Untuk mengakses aplikasi serta melakukan download dan upload bahan ajar materi perkuliahan dapat dilakukan dimana saja, tidak hanya di dalam lingkungan kampus.

Kekurangan

Keterbatasan utamanya ialah aplikasi ini memerlukan jaringan internet yang cukup kuat agar dapat mengakses iDINI untuk melakukan download file yang dilakukan oleh mahaasiswa maupun melakukan upload file yang dilakukan oleh dosen. Kemudian aplikasi ini hanya dapat digunakan oleh mahasiswa iLearning. Namun dengan keterbatasan ini program ini tetap menawarkan fasilitas yang cukup untuk membuat sebuah program media penyimpanan bahan ajar materi perkuliahan. 


\section{KESIMPULAN}

Berdasarkan uraian diatas, disimpulkan bahwa iDINI merupakan media pendukung yang tepat untuk metode pembelajaran iLearning, yang dapat memberikan informasi yang cepat dan efisien dalam mengakses seluruh data yang banyak dan tidak teratur di dalam media penyimpanan yang berupa sebuah aplikasi media penyimpanan bahan ajar materi perkuliahan, terlebih untuk suatu sistem informasi yang akurat.

\section{DAFTAR PUSTAKA}

[1] Rahardja Untung, (2011) "Definisi iLearning”. Raharja Enrichment Centre (REC). Tangerang.

[2] Untung Rahardja, Henderi, dan Djoko Soetarno (2007). "SIS: Otomatisasi Pelayanan Akademik Kepada Mahasiswa Studi Kasus di Perguruan Tinggi Raharja”. Jurnal Cyber Raharja. Edisi 7 Th IV/April 2007. Tangerang: Perguruan Tinggi Raharja.

[3] Heinich, R., Molenda, M., Russell, J. D., \& Smaldino, S.E. 2002. Instructional media and technology for learning, 7th edition. New Jersey: Prentice Hall, Inc.

[4] Ibrahim, H. "Pemanfaatan dan Pengembangan media slide pembelajaran bahan ajar". Disajikan dalam pelatihan produksi dan 
penggunaan media pembelajaran bagi dosen MDU Universitas Negeri Malang, 8 Februari s.d 6 Maret 1999.

[5] Gene Backlin "Professional iPhone and iPad Application Development". 2010

[6] Matthew Young Kim 2011 "Simulation Study of eLearning Classroom using iPads Based on Wireless LAN with IEEE 802.11b.

[7] Rory Lewis 2010 "iPhone and iPad Apps for Absolute Beginners”.

[8] Untung Rahardja, Dewi Imaniar, dan Siti Mawadah (2011). "iBooks Standardisation And Good Practice For Effective Education Methods In Support Of iLearning”. Jurnal CCIT Vol.5 No.1 September 2011. Tangerang: Perguruan Tinggi Raharja.

[9] Sukriya. "Perancangan Dan Pembuatan Perangkat Lunak E-Learning Berbasis .Net Menggunakan Teknologi Asp.Net 3.5 Dan Ajax Dengan Partial Rendering Untuk Studi Kasus Scored Online Test", Jurusan Teknik Informatika, Skripsi, Surabaya : ITS. 2009.

[10] Untung Rahardja, Dewi Imaniar, dan Reni Mulyani (2012). "Audio Visual One Of The Teaching Resources On iLearning”. Jurnal CCIT Vol. 5 No.2 Januari 2012. Tangerang: Perguruan Tinggi Raharja.

[11] Danny Wiliam Wongso. "Analisa dan Perancangan Piranti Lunak Pembangkit Soal Ujian Secara Online dengan menerapkan AJAX”. Skripsi, Jakarta : Bina Nusantara. 2008

[12] Qory Oktisa Aulia. Prototype dan Implementasi Metodologi Pembelajaran iLearning Pada Matakuliah Sistem Basis Data, Jurusan Sistem Informasi, Skripsi, Tangerang : Raharja. 2011 
